\title{
Molecular and cellular impact of Psoriasin (S100A7) on the healing of human wounds
}

\author{
ARAVINDAN RANGARAJ ${ }^{1,2}$, LIN YE $^{1}$, ANDREW JAMES SANDERS ${ }^{1}$, \\ PATRICIA ELAINE PRICE ${ }^{2}$, KEITH GORDON HARDING ${ }^{2}$ and WEN GUO JIANG ${ }^{1}$ \\ ${ }^{1}$ Cardiff China Medical Research Collaborative, Institute of Cancer and Genetics; \\ ${ }^{2}$ Department of Wound Healing, Cardiff University School of Medicine, CF14 4XN Cardiff, UK
}

Received October 27, 2015; Accepted October 21, 2016

DOI: $10.3892 / \mathrm{etm} .2017 .4275$

\begin{abstract}
Psoriasin, which is also known as S100A7, is a member of the S100 protein family, a group of calcium-responsive signalling proteins. Psoriasin expression remains high in patients with psoriasis, whereas it is downregulated in patients with invasive breast carcinoma. This observation suggests that this protein may be a notable marker of keratinocyte function and differentiation during wound healing. The aim of the present study was to determine the cellular impact of Psoriasin in keratinocytes, which are the primary cell type associated with wound healing. Psoriasin expression in wound tissues was examined using reverse transcription-quantitative polymerase chain reaction and immunochemical staining. Knockdown of Psoriasin in $\mathrm{HaCaT}$ cells was performed using anti-Psoriasin ribozyme transgenes and the effect on growth, adhesion and migration of keratinocytes was subsequently determined using in vitro cellular functional assays. Psoriasin expression is upregulated in wounds, particularly at the wound edges. The present study demonstrated that Psoriasin is expressed in keratinocytes and is a fundamental regulator of keratinocyte migration. Significant increases in the rate of keratinocyte adhesion, migration and growth were observed in Psoriasin-deficient cells $(\mathrm{P}<0.01$ vs. control). Application of small inhibitors identified the potential association of neural Wiskott-Aldrich syndrome protein, focal adhesion primase and rho-associated protein kinase signalling pathways with Psoriasin-regulated cell adhesion and motility. In conclusion, Psoriasin serves an important role in the wound healing process, suggesting that it may be utilized as a potential wound healing biomarker.
\end{abstract}

Correspondence to: Dr Lin Ye, Cardiff China Medical Research Collaborative, Institute of Cancer and Genetics, Cardiff University School of Medicine, Henry Wellcome Building, Heath Park, CF14 4XN Cardiff, UK

E-mail: yel@cf.ac.uk

Key words: Psoriasin, wound healing, migration, adhesion and proliferation

\section{Introduction}

Chronic wounds, such as diabetic foot ulcers and venous and arterial leg ulcers, pose a major health risk to patients and place marked financial, resource and time burdens on the healthcare system. In industrialised countries, $\sim 1 \%$ of the population experiences a non-healing wound, which accounts for a significant part of the healthcare budget (1). In 1998, it was estimated that chronic wounds would cost the National Health Service in the United Kingdom (UK) a total of $£ 1$ billion per year (2). Between 2005 and 2006, there were 200,000 individuals in the UK with chronic wounds, accounting for £2.3-3.1 billion per year, or $3 \%$ of the total estimated out-turn expenditure on health for the same period ( $£ 89.4$ billion) $(2,3)$. The cost may become much higher as the number of people suffering from chronic wounds in the UK increases; for example, in 2011, this figure was estimated to be $>600,000$ (4).

Advances in molecular biology have helped to elucidate the complexities of wound biology. Menke et al (5) describe the nature of wound healing biology as 'complex, multiscale, multitemporal and hierarchical'. Past failures in wound diagnosis and monotherapies may be due to the under appreciation of this complexity. The signalling mechanisms of growth factors have been well studied $(6,7)$, and reduced levels in the wound environment may be partially responsible for the failure of certain wounds to heal. It has been demonstrated that chronic ulcers exhibit reduced levels of platelet derived growth factor, epidermal growth factor, basic fibroblast growth factor, and transforming growth factor $\beta$ compared with acute wounds, typically as a result of trapping or degradation $(6,7)$.

The imbalance between proteinases and their inhibitors with excessive proteinase activity in chronic wounds, which is potentially due to the overexpression of matrix metalloproteinase, results in abnormal degradation of the extracellular matrix (8-10). Dermal fibroblasts exhibit an age-related decrease in proliferation potential, or cell senescence, and it has previously been demonstrated that fibroblasts isolated from chronic wounds have a decreased or non-existent replicative ability (11). In addition, cell senescence, in the form of epidermal arrest, has been demonstrated in keratinocytes (12). Further studies have shown that gene arrays of wound edges are able to guide specific cell subpopulations, which aid in targeting therapy and debridement $(13,14)$. 
Charles et al (15) compared the gene expression patterns of five non-healing venous leg ulcers with five healing venous leg ulcers, and 15 genes were identified that were differentially expressed in the keratinocytes at the non-healing wound edge. Among these was the S100 calcium-binding protein A7 gene (Psoriasin), which expresses protein products that have been proposed to be associated with keratinocyte differentiation.

Psoriasin, which is also known as S100A7, belongs to the S100 protein family of calcium-responsive signalling proteins. It was originally discovered in unfractionated non-cultured keratinocytes as a novel protein with a low molecular weight $(11.4 \mathrm{kDa})(16,17)$. It was found to be overexpressed in psoriatic keratinocytes and expressed at low levels in normal proliferating keratinocytes and foetal skin (16). Although Psoriasin was initially studied as a secreted protein in psoriatic skin (17), it was later detected in the cytoplasm and nucleus of keratinocytes and breast epithelial cells (18), suggesting that this protein has multiple functions. Psoriasin is homologous with the S100 genes as it encodes small cytoplasmic and secreted proteins that share EF-hand-helix-loop-helix domains, which are necessary for calcium binding (19). A total of 13 of the S100 proteins, including Psoriasin, are encoded within the epidermal differentiation complex of human chromosome 1q21.2-q22 (18,20,21). Many of these genes products, including Psoriasin, serve important roles in exerting the effects of calcium on cell growth and differentiation (22).

Although Psoriasin protein overexpression was initially discovered in patients with psoriasis (16), it has subsequently been discovered to be associated with other inflammatory skin conditions (23). Secreted Psoriasin has been demonstrated to have a chemotactic influence on inflammatory cells, suggesting a link with inflammatory skin diseases (24). The levels of Psoriasin in pre-cancerous lesions of the breast and skin, as demonstrated in multiple studies (25-28), indicate that Psoriasin expression is low in normal epithelium and increased in pre-invasive carcinoma, specifically act in keratosis and breast carcinoma in situ, and that high Psoriasin levels are associated with unfavourable histological features and a worse clinical outcome in patients with breast cancer (29-33). This suggests that Psoriasin may serve an important role in cancer progression.

Expression of Psoriasin in normal keratinocytes is known to be upregulated in response to calcium and retinoic acid stimuli, and in abnormal pathways of differentiation in culture $(18,25,34)$. Among normal tissues, Psoriasin has restricted expression in the epithelial component of tissues, such as skin, breast and bladder $(23,25,29,35)$. Furthermore, expression is elevated in the differentiating layers compared with the basal cells, where Psoriasin is absent, thereby indicating that it may have a specific association with differentiation $(25,36)$. Expression of Psoriasin in the context of wound healing was initially observed based on the regenerative similarities among wounds and psoriatic keratinocyte $(37,38)$. The effects of Psoriasin in chronic venous ulcers were previously studied by Dressel et al (39) via immunohistochemical (IHC) staining, demonstrating a significant induction of Psoriasin among seven chronic venous wound margin biopsies compared with normal skin biopsies.

Psoriasin is important in many basic cellular functions and keratinocytes are associated with the re-epithelisation of wound edges. Psoriasin expression in the epidermis and its association with the regulation of survival, adhesion and motility of various types of cells, suggests that it may have a function in aiding wound healing. The aim of the present study was to investigate the specific role of Psoriasin in keratinocyte cellular functions and its implication in chronic wounds.

\section{Materials and methods}

Materials and cell line. A universal IHC kit (Elite ABC Kit) was purchased from Vector Laboratories, Ltd. (Peterborough, UK). Total RNA isolation reagent (TRIzol) was purchased from Sigma-Aldrich (Merck Millipore, Darmstadt, Germany), and reverse transcription kits (iScript) were obtained from Bio-Rad Laboratories, Inc. (Hercules, CA, USA). Small inhibitors for neural Wiskott-Aldrich syndrome protein (N-WASP), focal adhesion kinase (FAK) and rho-associated protein kinase (ROCK) were purchased from Merck Millipore. The HaCaT human keratinocyte cell line was purchased from The German Cancer Research Center (Heidelberg, Germany). Cells were maintained in Dubecco's modified Eagle medium (DMEM), which was supplemented with penicillin, streptomycin and $10 \%$ fetal calf serum (PAA Laboratories, Ltd.; GE Healthcare Life Sciences, Chalfont, UK). Cells were incubated at $37^{\circ} \mathrm{C}$ and $95 \%$ humidity in an atmosphere containing $5 \% \mathrm{CO}_{2}$. Primer sequences are provided in Table I.

Chronic wound tissues and skin biopsies. Skin biopsies were obtained from patients attending the University Hospital of Wales (Cardiff, UK) wound healing clinic as described previously $(40,41)$. Ethical approval was granted by the Local Research Ethics Committee and written informed consent was obtained from each patient. Biopsies were taken from 14 patients with chronic leg ulcers and used during the present study. All wounds were present for $\geq 6$ months, displaying no evidence of healing occurring six weeks prior to biopsy and had a minimum area of $4 \mathrm{~cm}^{2}$ prior to biopsy with no clinical indications of infection. Venous disease was diagnosed by duplex ultrasonography using a Viamo system (Toshiba Medical Systems, Ltd., Crawley, UK). Following the administration of local anaesthetic (1\% lidocaine; Hameln Pharmaceuticals, Ltd., Gloucester, UK), $6 \mathrm{~mm}$ punch biopsies, incorporating epidermis and dermis at the wound edge with adjacent granulation tissue, were harvested from the wound margin under aseptic conditions. Single wedge biopsies were obtained from 10 patients with acute surgical wounds following excision of pilonidal disease. These wounds were determined to be clinically non-infected. Biopsies were harvested from the edge of the healing wound within six weeks of excision surgery. Normal, unwounded skin was also obtained and examined as a control to provide a comparison with wound tissue. Under local anaesthetic (1\% lidocaine), $3 \mathrm{~mm}$ punch biopsies were taken from the inner aspect of the upper arm of 10 healthy volunteers working within the Wound Healing Research Unit at the University Hospital of Wales.

IHC staining. Frozen sections from wound tissues were fixed in an acetone/methanol solution and rehydrated in wash buffer (Mena Path Autowash buffer; A. Menarini Diagnostics, Ltd., Winnersh, UK) and placed in a wash buffer solution 
Table I. Primer sequences used for PCR.

\begin{tabular}{lll}
\hline Primer & \multicolumn{1}{c}{ Forward } & \multicolumn{1}{c}{ Reverse } \\
\hline Psoriasin & 5'-GAGGTCCATAATAGGCATGA-3' & 5'-AGCAAGGACAGAAACTCAGA-3' \\
Psoriasin (qPCR) & 5'-TGTGACAAAAAGGGCACAAA-3' & 5'-ACTGAACCTGACCGTACACCCAGCAA \\
& & GGACAGAAACTC-3' \\
GAPDH & 5'-ATGATATCGCCGCGCTCGTC-3' & 5'-GCTCGGTCAGGATCTTCA-3' \\
GAPDH (qPCR) & 5'-CTGAGTACGTCGTGGAGTC-3' & 5'-ACTGAACCTGACCGTACAGAGATGATG \\
& & ACCCTTTTG-3' \\
Psoriasin ribozyme & 5'-CTGCAGTCACAGGCACTAAGG & 5'-ACTAGTGGCTGGTGTTTGAC \\
& AAGTTGGGCTGATGAGTCCGTGAGGA-3' & ATTTCGTCCTCACGGACT-3' \\
\hline
\end{tabular}

PCR, polymerase chain reaction; qPCR, quantitative PCR.

containing $10 \%$ horse serum (Vector Laboratories, Ltd.) to block non-specific antigen binding. An avidin/biotin complex (ABC) IHC kit (PK-6200, Vector Laboratories, Ltd.) was used. An anti-Psoriasin polyclonal antibody, was diluted in a buffer that contained $1 \%$ horse serum and $0.1 \%$ Tween 20 (Sigma-Aldrich; Merck Millipore) at 1:40 dilution. Following $1 \mathrm{~h}$ of incubation at room temperature with the primary antibodies, the slides were washed four times in wash buffer and incubated at room temperature with a universal biotinylated secondary antibody provided in the IHC kit (1:500; Vector Laboratories, Ltd.) for $30 \mathrm{~min}$. Avidin and biotin were added through the addition of the ABC complex following washing. A 3,3'-diaminobenzidinecolour developing system was used to indirectly detect protein staining. A series of graded alcohols were used to dehydrate sections, which were subsequently cleared in xylene, mounted and examined using a light microscope equipped with a digital camera (Olympus Corporation, Tokyo, Japan). Semi-quantification was performed using ImageJ software (version 1.5; National Institutes of Health, Bethesda, MD, USA), with normalisation of data to the background.

Psoriasin knockdown in HaCaT cells. Anti-Psoriasin hammerhead ribozymes were designed based on the secondary structure of Psoriasin mRNA. The ribozymes were synthesised using a touchdown PCR procedure and subsequently cloned into a mammalian expression vector ( $\mathrm{pEF} 6 / \mathrm{His}$ TOPO vector; Invitrogen; Thermo Fisher Scientific, Inc., Waltham, MA, USA). The constructed anti-Psoriasin transgenes and empty vectors were transfected into $\mathrm{HaCaT}$ cells according to a previously reported procedure (42). Following a period of blasticidin selection (5 $\mu \mathrm{g} / \mathrm{ml}$; Sigma-Aldrich; Merck Millipore), the cells were maintained in DMEM containing $0.5 \mu \mathrm{g} / \mathrm{ml}$ blasticidin. The selected transfectants were verified for the knockdown of Psoriasin $\left(\mathrm{HaCaT}^{\mathrm{PSOkd}}\right) . \mathrm{HaCaT}^{\mathrm{PSOkd}}$, together with the control cells transfected with empty vectors $\left(\mathrm{HaCaT}^{\mathrm{EF})}\right.$ and wild type cells $\left(\mathrm{HaCaT}^{\mathrm{WT}}\right)$, were used in the following experiments. Three independent transfections were performed to verify the knockdown of Psoriasin using the anti-Psoriasin ribozymes.

RNA extraction, reverse transcription $(R T)$, conventional polymerase chain reaction (PCR) and quantitative $(q) P C R)$.
RNA isolation from cells or tissues was performed using an ABgene Total RNA Isolation Reagent (TRIR) Kit (ABgene; Thermo Fisher Scientific, Inc.) in accordance with the manufacturer's protocol. Briefly, cells were cultured in $25 \mathrm{~cm}^{2}$ flasks until $85-90 \%$ confluent. The growth medium was subsequently removed and $1 \mathrm{ml}$ of TRIR reagent was added to the monolayer to lyse the cells. Following RNA isolation, RNA was quantified using a UV1101 photometer (WPA Biochrom; Biochrom, Ltd., Cambridge, UK) at $260 \mathrm{~nm}$. cDNA was synthesised using an iScript cDNA synthesis kit (Bio-Rad Laboratories) for a standardised $0.5 \mu \mathrm{g}$ RNA in a $20 \mu$ l-reaction. Conventional PCR was subsequently used to verify Psoriasin expression in transfected cells using REDTaq ReadyMix PCR reaction mixture comprising $20 \mathrm{mM}$ Tris- $\mathrm{HCl}(\mathrm{pH} 8.3)$ with $100 \mathrm{mM}$ $\mathrm{KCl}, 3 \mathrm{mM} \mathrm{MgCl}$, $0.002 \%$ gelatin, $0.4 \mathrm{mM}$ dNTP mix (dATP, dCTP, dGTP, TTP), stabilizers, and $0.06 \mathrm{U} / \mathrm{ml}$ Taq DNA Polymerase (R2523; Sigma-Aldrich; Merck Millipore) and a T-Cy thermocycler (Creacon Technologies, B.V., Emmen, the Netherlands). Conditions for conventional PCR to amplify transcripts of Psoriasin were: 36 cycles at $94^{\circ} \mathrm{C}$ for $30 \mathrm{sec}$, $55^{\circ} \mathrm{C}$ for $20 \mathrm{sec}, 72^{\circ} \mathrm{C}$ for $30 \mathrm{sec}$ and a final extension phase of $7 \mathrm{~min}$ at $72^{\circ} \mathrm{C}$. GAPDH was used as a housekeeping gene. PCR products were separated on a $1.5 \%$ agarose gel and stained with ethidium bromide prior to examination under UV light.

qPCR was used to determine Psoriasin transcripts in wound tissues following a previously reported method (43). An iCycler IQ system (Bio-Rad Laboratories, Inc.) was used to determine Psorisain transcript levels. Each reaction contained $5 \mu \mathrm{l}$ of the 2x concentrated HotstarTaq-master mix (ABgene; Thermo Fisher Scientific, Inc.), $1 \mu 1$ of forward primer (10 pmol/ $\mu 1)$, $1 \mu \mathrm{l}$ reverse primer $(1 \mathrm{pmol} / \mu \mathrm{l}), 1 \mu \mathrm{l}$ of a FAM-tagged universal probe (10 pmol $/ \mu 1$; Intergen Co., Purchase, NY, USA), and cDNA samples. Conditions for qPCR were as follows: An initial 10 min $95^{\circ} \mathrm{C}$ denature followed by 80 cycles of $95^{\circ} \mathrm{C}$ for $15 \mathrm{sec}, 55^{\circ} \mathrm{C}$ for $35 \mathrm{sec}$ and $72^{\circ} \mathrm{C}$ for $20 \mathrm{sec}$. Psoriasin transcript levels were normalised against corresponding GAPDH quantity. Primer sequences are provided in Table I.

SDS-PAGE and western blot analysis. Cellular protein was extracted and lysed in $\mathrm{Ca}^{2+}$ and $\mathrm{Mg}^{2+}$ free HEPES buffer containing $0.5 \%$ SDS, $1 \%$ Triton X-100, $2 \mathrm{mM} \mathrm{CaCl}_{2}, 100 \mu \mathrm{g} / \mathrm{ml}$ phenylmethylsulfonyl fluoride, $1 \mathrm{mg} / \mathrm{ml}$ leupeptin, $1 \mathrm{mg} / \mathrm{ml}$ aprotinin and, $10 \mathrm{mM}$ sodium orthovanadate (Sigma-Aldrich; 
Merck Millipore) on a rotor wheel for $1 \mathrm{~h}$. Insoluble proteins were removed via centrifugation at $13,000 \times \mathrm{g}$ for $4^{\circ} \mathrm{C}$ for 15 min and quantified using a DC Protein Assay kit (Bio-Rad Laboratories, Inc.). Samples were standardised and diluted in Laemmli 2x concentrate sample buffer (Sigma-Aldrich; Merck Millipore) and boiled for $5 \mathrm{~min}$. Following this, $20 \mu \mathrm{g}$ total protein of each sample were separated by $12 \%$ SDS-PAGE. The separated proteins were transferred to a nitrocellulose membrane via western blotting. Gels were removed from the electrophoretic tank and unclipped from the loading cassette, and the stacking gel was removed. The resulting gel was then carefully laid on top of a pre-cut Hybond nitrocellulose membrane (GE Healthcare Life Sciences) in an SD20 Maxi System blotting unit (SemiDRY; Wolf Laboratories, Ltd., York, UK). Blots were probed with anti-Psoriasin $(1: 250$; ab13680; Abcam, Cambridge, UK) and anti-GAPDH (1:500, SC-47724, Insight Biotechnology, Ltd., Wembley, UK) mouse monoclonal antibodies following an overnight incubation with a blocking buffer which was $10 \%$ skimmed milk in tris-buffered saline (TBS) at $4^{\circ} \mathrm{C}$. Peroxidase-conjugated anti-mouse antibody (1:1,000; A9044; Sigma-Aldrich; Merck Millipore) was then added prior to visualising protein bands using the Supersignal West Dura system (Thermo Fisher Scientific, Inc.) and a gel imaging system (UVItec, Ltd., Cambridge, UK). The experiment was repeated three times at least for each subline.

In vitro growth assay. An in vitro growth assay was used to determine HaCaT cell growth. A total of 3,000 cells per well were seeded into 96 well plates. Triplicate plates were set up and incubated at $37^{\circ} \mathrm{C}$ for three and five-day periods prior to analyses. Following incubation, the plates were fixed in $4 \%$ formaldehyde (v/v), stained with $0.5 \%(\mathrm{w} / \mathrm{v})$ crystal violet and treated with $10 \%$ acetic acid (v/v). Absorbance at $540 \mathrm{~nm}$ was determined using an ELx800 multi-plate reader (BioTek Instruments Inc., Winnoski, VT, USA).

Adhesion and migration tests using electric cell-substrate impedance sensing (ECIS) analysis. The ECIS 9600 system (Applied Biophysics Inc., Troy, NY, USA) was used to monitorthe adhesion and migration of $\mathrm{HaCaT}$ cells, as previously described $(44,45)$. Briefly, HaCaT cells were seeded onto ECIS $96 \mathrm{~W} 1 \mathrm{E}$ arrays and adhesion of cells to the culture surface and electrodes was monitored via measuring electrical resistance. Once a confluent monolayer had been formed, the cells were damaged by applying electric current $(1,400 \mu \mathrm{A}, 60 \mathrm{kHz})$ for $20 \mathrm{sec}$ to create a break in the cell monolayer. The rate of change in impedance as cells migrated back onto the electrode was subsequently monitored and analysed.

Statistical analysis. The Minitab 14 statistical package (Minitab, Inc., State College, PA, USA) was used to identify statistically significant differences between the test groups using a two-sample, two-tailed, Student's $t$-test. In vitro functional assays were repeated a minimum of three times. $\mathrm{P}<0.05$ was considered to indicate a statistically significant difference.

\section{Results}

Expression of Psoriasin in chronic wounds. Frozen sections of chronic wound tissue samples were stained to detect Psoriasin, as described previously, and tissue sections from the wound edge and distal edge were compared. IHC stained images from the 12 wound samples are presented in Fig. 1A. Staining of Psoriasin revealed elevated protein levels throughout all epidermal layers in wounds, with the exception of the stratum basale. Furthermore, keratinocytes also demonstrated an increase in Psoriasin staining, in accordance with the secretory nature of the protein. Initial comparisons between samples revealed a less intense immunostaining of Psoriasin at the distal edges of the wounds compared with the wound edges. Semi-quantification using Image J software revealed an increase $\leq 19.8 \%$ in the intensity of Psoriasin staining within the epidermal layers at the wound edge, in comparison with the epidermal staining at the distal wound (Fig. 1B). This indicates an upregulation of Psoriasin in the wound edges. Psoriasin mRNA transcript in tissues taken from the edge of acute and chronic wounds and normal skin was analysed (Fig. 1C). In acute wounds, there was a significant increase in Psoriasin mRNA expression $(\mathrm{P}=0.0021)$ compared with the chronic wound phenotype. A significant increase was also observed in Psoriasin expression between the acute wounds and the normal skin controls $(\mathrm{P}=0.037)$. Furthermore, Psoriasin expression was markedly lower in chronic wounds compared with the normal controls.

Knockdown of Psoriasin in HaCaT cells. The presence of Psoriasin in $\mathrm{HaCaT}$ keratinocytes was confirmed using RT-qPCR. To examine the functional role of Psoriasin in keratinocytes, $\mathrm{HaCaT}$ cells were transfected with anti-Psoriasin ribozyme transgenes. HaCaT Psoriasin knockdown in the $\mathrm{HaCaT}^{\text {PSOkd }}$ cells was seen and its mRNA expression compared with the $\mathrm{HaCaT}^{\mathrm{WT}}$ and $\mathrm{HaCaT}^{\mathrm{pEF}}$ control cells using RT-qPCR (Fig. 2A and B). Resulting protein levels of Psoriasin in $\mathrm{HaCaT}^{\mathrm{pEF}}$ and $\mathrm{HaCaT}^{\mathrm{PSOkd}}$ cells were evaluated using western blot analysis. As illustrated in Fig. 2C, Psoriasin protein was detected in the $\mathrm{HaCaT}^{\mathrm{pEF}}$ control cells with a corresponding reduction of Psoriasin protein levels in the $\mathrm{HaCaT}^{\mathrm{PSOkd}}$ cells. Semi-quantifications showed a $41 \%$ reduction of Psoriasin protein expression in $\mathrm{HaCaT}^{\mathrm{PSOkd}}$ cells compared with the control cells (Fig. 2D).

Influence of Psoriasin knockdown on in vitro growth, adhesion and migration of HaCaT cells. Using the colorimetric growth assay method described previously, the effects of Psoriasin knockdown on HaCaT cells were evaluated and compared with the $\mathrm{HaCaT}^{\mathrm{pEF}}$ controls. Psoriasin knockdown significantly enhanced the growth rate of $\mathrm{HaCaT}^{\mathrm{PSOkd}}$ cells at three and five days compared with control $\mathrm{HaCaT}^{\mathrm{pEF}}$ cells (both $\mathrm{P}<0.01$; Fig. 3A).

ECIS assay was performed to evaluate cell adhesion and migration. Cell adhesion was calculated by assessing the increase in the mean resistance at $2 \mathrm{~h}$ following cell seeding, and increased adhesion was demonstrated in the Psoriasin knockdown cells compared with the control cells (Fig. 3B). At 4-5 h, when adhesion was complete, as determined by the plateauing of resistance readings, the confluent monolayer of cells was damaged by passing a high voltage current through it via an electrode. Migration was then calculated from the subsequent mean resistances recorded at $0,1,2,3$ and $4 \mathrm{~h}$ (Fig. 3C). It was shown that the migration of $\mathrm{HaCaT}^{\text {PSOkd }}$ cells increased significantly $(\mathrm{P}<0.01)$ when compared with $\mathrm{HaCaT}^{\mathrm{pEF}}$ cells. 

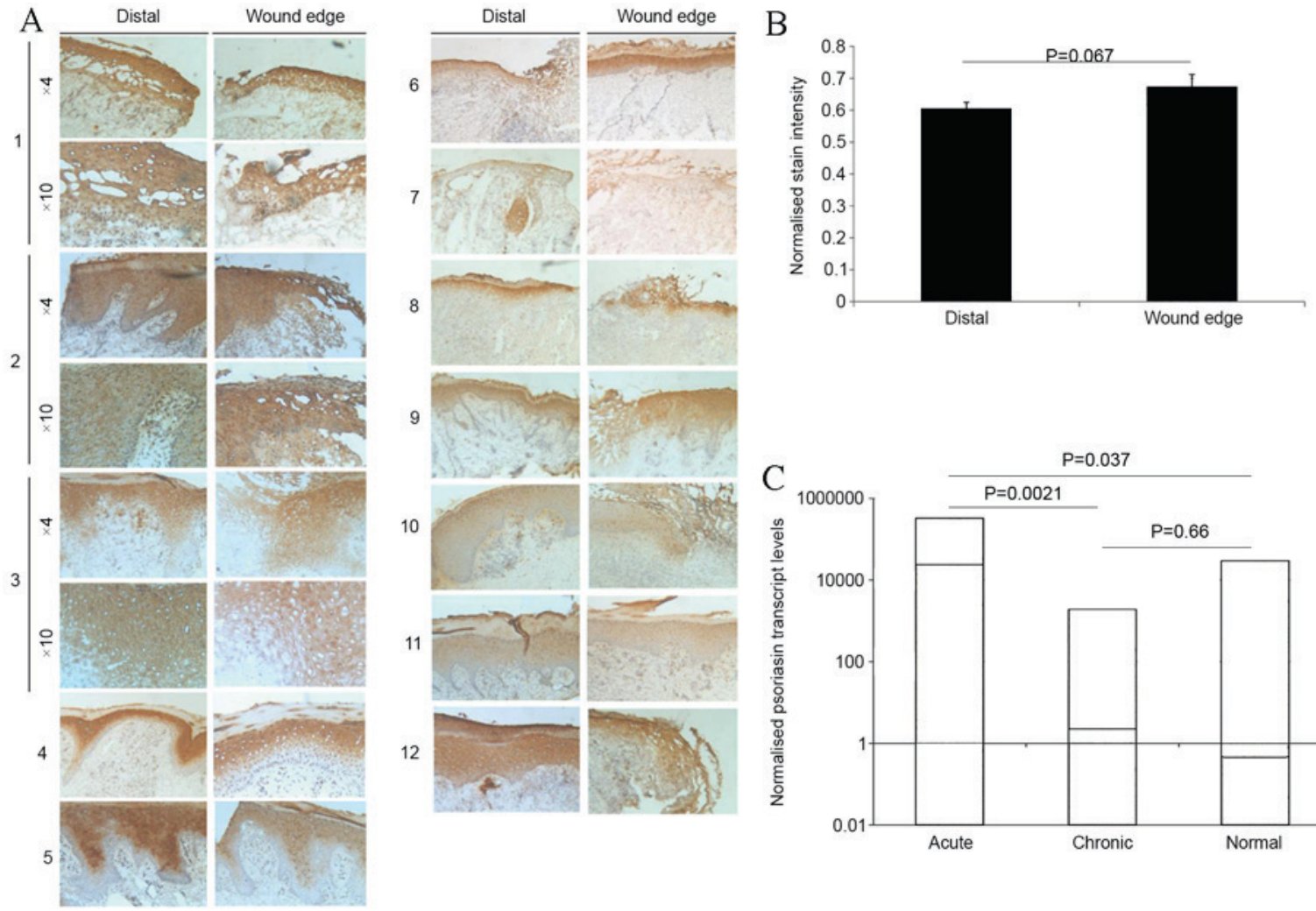

Figure 1. Expression of Psoriasin in wound tissues. (A) Immunochemical staining of Psoriasin in wound tissues (n=12) is shown in wound edges compared with staining in matched distal area. Images 4-12 were reduced from images captured at $x 4$ magnification. (B) Semi-quantitative analysis of the immunochemical Psoriasin staining intensity at the wound edge and the distal wound. Staining intensity in 12 wound samples was analysed using ImageJ software. Three separate readings within the epidermal layers were normalised to the background. Means of these readings arepresented \pm standard error of the mean. A $19.8 \%$ relative increase of Psoriasin staining in the wound edge is observed, compared with the distal wound $(\mathrm{P}=0.067)$. (C) Quantity of Psoriasintranscripts in acute and chronic wounds and normal skin was determined using quantitative polymerase chain reaction. Psoriasin transcript levels were normalised against their corresponding GAPDH. Due to the spread of data, the y-axis is presented as a logarithmic scale. There is a significant difference between the acute and chronic wounds $(\mathrm{P}=0.0021)$ and between the acute wound and the normal skin $(\mathrm{P}=0.037)$. There is no significant difference between the chronic wound and normal skin $(\mathrm{P}=0.66)$.
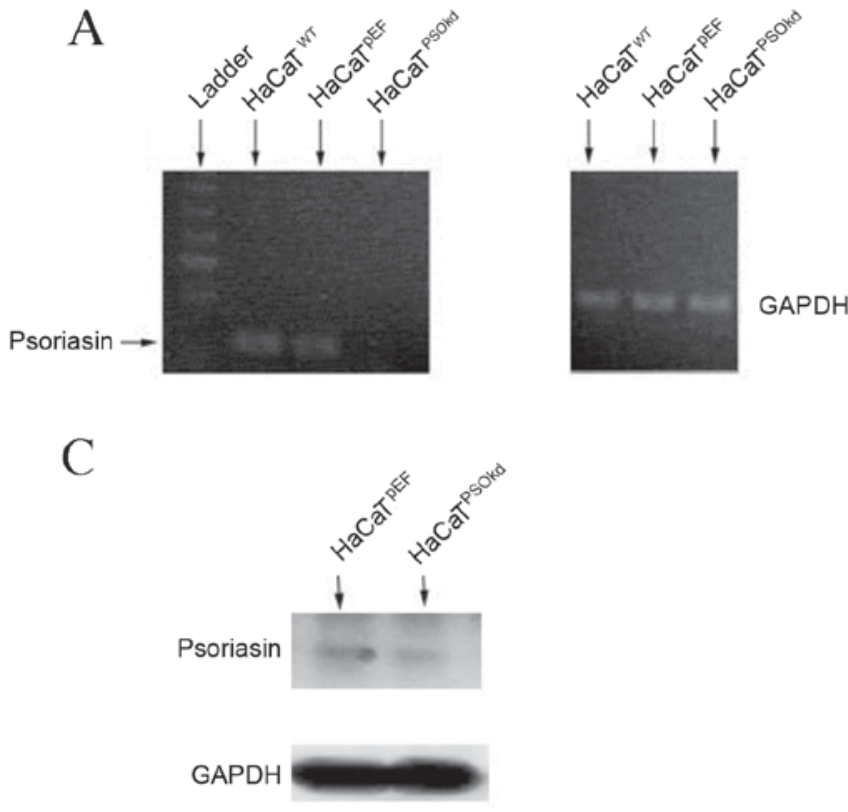

$\mathrm{B}$

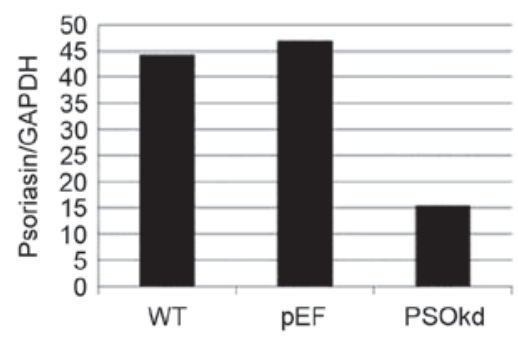

$\mathrm{D}$

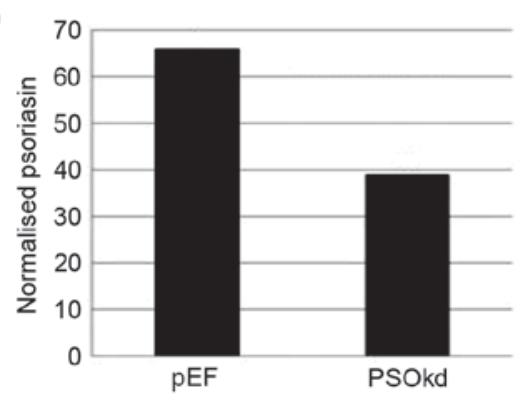

Figure 2. Psoriasin knockdown in HaCaT cells. (A) Agarose gel electrophoresis following reverse transcription-quantitative polymerase chain reaction demonstrate successful Psoriasin knockdown by the absence of a band at $246 \mathrm{bp}$. The internal control GAPDH is displayed alongside. (B) Knockdown of Psoriasin at the mRNA level was also confirmed using quantitative polymerase chain reaction. Displayed are Psoriasin transcripts (copies) normalised against corresponding GAPDH controls. (C) Western blot analysis for expression of Psoriasin protein in HaCaT cells revealed that reduced levels of Psoriasin protein expression in $\mathrm{HaCaT}^{\mathrm{PSOkd}}$ cells in comparison with $\mathrm{HaCaT}^{\mathrm{EF}}$ control cells. (D) Subsequent semi-quantitative analysis and normalisation to GAPDH indicates a marked decrease in Psoriasin expression following transfection with the ribozyme transgene. WT, wild type; pEF, transfected with an empty vector; PSOkd, Psoriasin knockdown. 

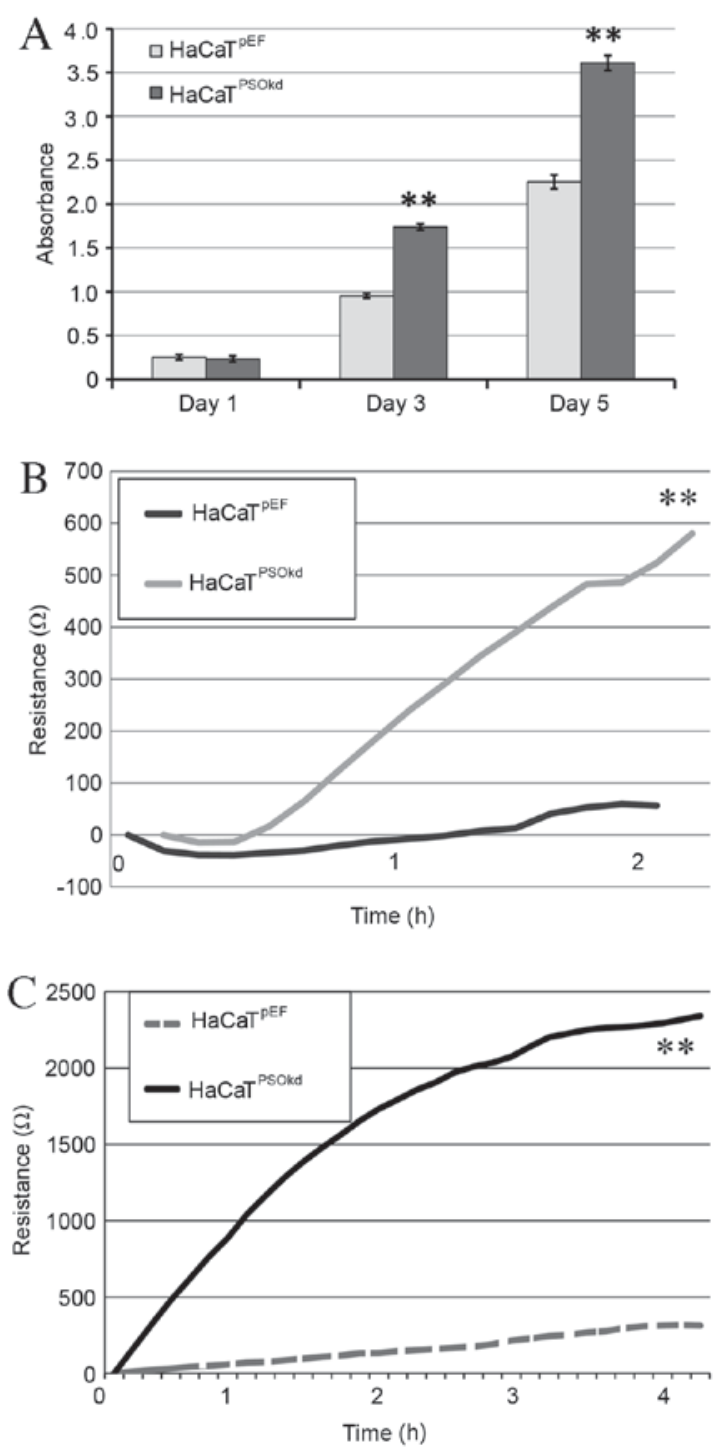

Figure 3. Influence of Psoriasin knockdown on cellular functions of HaCaT cells. (A) Effect on cell growth was assessed using a colormetric assay with crystal violet staining and absorbance was measured at $540 \mathrm{~nm}$. (B) Adhesion and (C) migration of $\mathrm{HaCaT}$ cells were determined using electric cell-substrate impedance sensingassays. Six repeats of each group were performed in each experiment. Six repeats were included in each adhesion assay while triplicates for each cell lines were included in each migration assay. Three independent experiments were performed. Data are presented as the mean \pm standard error of the mean. ${ }^{* *} \mathrm{P}<0.01$ vs. the corresponding $\mathrm{HaCaT}^{\mathrm{pEF}}$ cells. pEF, transfected with an empty vector; PSOkd, Psoriasin knockdown.

Association of N-WASP, ROCK and FAK with Psoriasin-regulated cell adhesion and migration. To elucidate the underlying mechanisms that alter the adhesion and migration of $\mathrm{HaCaT}$ cells following knockdown of Psoriasin, small molecule inhibitors were used to evaluate the roles of some associated molecules. N-WASP inhibitor wiskostatin was used at a concentration of $200 \mathrm{nM}$. In the presence of the $\mathrm{N}$-WASP inhibitor, $\mathrm{HaCaT}^{\text {PSOkd }}$ demonstrated a significant reduction in adhesion rate $(\mathrm{P}<0.001$; Fig. $4 \mathrm{~A})$. The relative percentage of inhibition compared with the corresponding untreated cell line was $79 \%$ for $\mathrm{HaCaT}^{\mathrm{pFF}}$ and $77.4 \%$ for $\mathrm{HaCaT}^{\mathrm{PSOkd}}$, which is significant. N-WASP inhibition induced a reduction in the rate of keratinocyte migration across a
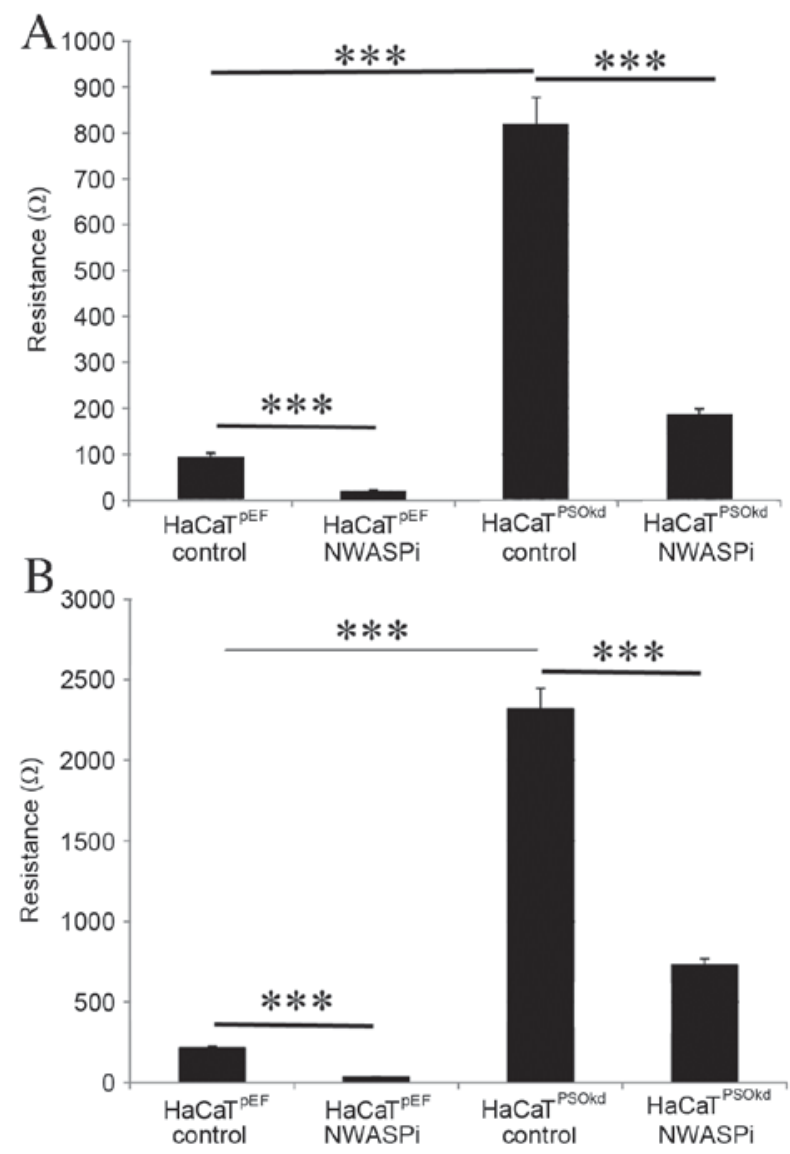

Figure 4. Association of N-WASP in the Psoriasin knockdown altered adhesion and migration of HaCaT cells. (A) Adhesion of HaCaT cells was determined using an electric cell-substrate impedance sensing assay. A significant increase was observed in the rate of adhesion in $\mathrm{HaCaT}^{\text {PSOkd }}$ compared with $\mathrm{HaCaT}^{\mathrm{EF}}(\mathrm{P}=0.002)$. N-WASP inhibition significantly reduces the rate of adhesion in $\mathrm{HaCaT}^{\mathrm{pEF}}$ and $\mathrm{HaCaT}^{\mathrm{PSO} \text { okd }}$ cell lines. The relative percentage of the inhibition in the $\mathrm{HaCaT}^{\mathrm{pFF}}$ cell line is $79 \%$ and in $\mathrm{HaCaT}^{\mathrm{PSOkd}}$ is $77.4 \%$. (B) Effect of N-WASP inhibitor on migration of $\mathrm{HaCaT}$ cells. Inhibition with N-WASP demonstrated a significant reduction in the rate of cell migration. The relative percentage of reduction in migration with N-WASP inhibitor in $\mathrm{HaCaT}^{\mathrm{pEF}}$ is $85 \%$ and in $\mathrm{HaCaT}^{\mathrm{PSOkd}}$ is $68.6 \%$ Experiments were repeated four times. The absolute resistance is presented as the mean \pm the standard error of the mean. ${ }^{* * *} \mathrm{P}<0.001$. N-WASP, neural Wiskott-Aldrich syndrome protein; i, inhibition; $\mathrm{pEF}$, transfected with an empty vector; PSOkd, Psoriasin knockdown.

wound similar to the effect on adhesion (Fig. 4B). The effect of inhibition in both cell lines was significant $(\mathrm{P}<0.001)$, and comparing the relative percentile of reduction $\left(\mathrm{HaCaT}^{\mathrm{pEF}}\right.$, 85\%; $\mathrm{HaCaT}^{\mathrm{PSOkd}}, 68.6 \%$ ), it appears that N-WASP inhibition is less effective at reducing cell migration in the Psoriasin knockdown cells.

ROCK inhibitor significantly increased $(\mathrm{P}<0.001)$ the rate of cell adhesion in the $\mathrm{HaCaT}^{\mathrm{pF}}$ cell line by a factor of $163 \%$, as demonstrated in Fig. 5A. However, in the $\mathrm{HaCaT}^{\mathrm{PSOkd}}$ cells ROCK inhibitor induced a significant reduction $(\mathrm{P}<0.01)$ in the rate of cell adhesion, with a percentile difference of $45 \%$. The $\mathrm{HaCaT}$ cell adhesion rate in the $\mathrm{HaCaT}^{\mathrm{PSOkd}}$ group remained higher compared with that of the $\mathrm{HaCaT}^{\mathrm{pEF}}$ control group. The pattern of influence on migration was similar to that seen for adhesion (Fig. 5B). HaCaT ${ }^{\mathrm{EF}}$ cells continued to demonstrate a significant increase $(\mathrm{P}<0.01)$ in cell migration in the presence of ROCK inhibitor, whereas the $\mathrm{HaCaT}^{\text {PSOkd }}$ cells exhibited a 

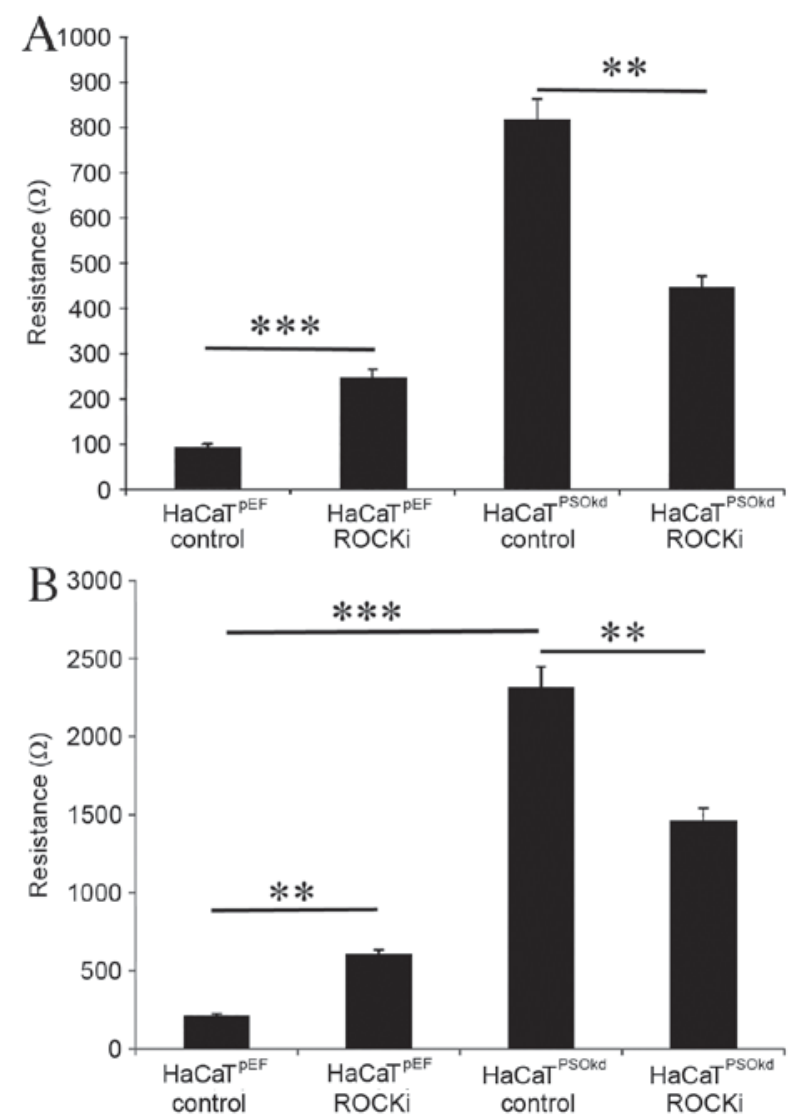

Figure 5. Association of ROCK in the Psoriasin knockdown altered adhesion and migration of $\mathrm{HaCaT}$ cells. (A) There is a statistically significant increase in the rate of adhesion in the $\mathrm{HaCaT}^{\mathrm{pEF}}$ cell population following $\mathrm{ROCK}$ inhibition, with a relative increase of $163 \%$ in comparison with the control. Conversely, $\mathrm{HaCaT}^{\mathrm{PSO} O \mathrm{kd}}$ demonstrate a significant inhibition of cell adhesion in the presence of ROCK inhibitors with a relative percentage of $45 \%$. (B) There is a $181 \%$ increase in the rate of migration of the $\mathrm{HaCaT}^{\mathrm{pF}}$ cells following ROCK inhibition and this is significant on two-tail $t$-test $(\mathrm{P}<0.001)$. Within the $\mathrm{HaCaT}^{\mathrm{PSOkd}}$ cells the reduction in the rate of cell migration is also significant and by a relative $43 \%$. Experiments were repeated four times. The absolute resistance is presented as the mean \pm the standard error of the mean. ${ }^{* * *} \mathrm{P}<0.01 ;{ }^{* * *} \mathrm{P}<0.001$. ROCK, rho-associated protein kinase; i, inhibition; $\mathrm{pEF}$, transfected with an empty vector; PSOkd, Psoriasin knockdown.

reduction in cell migration in the presence of ROCK inhibitor $(\mathrm{P}<0.01)$.

$\mathrm{HaCaT}^{\mathrm{EF}}$ cell adhesion was increased with FAK inhibition, as illustrated in Fig. 6A. However, FAK inhibition induced a reduction in cell adhesion rate in $\mathrm{HaCaT}^{\mathrm{PSOkd}}$ cells. Both changes were significant $(\mathrm{P}<0.001)$ compared with untreated equivalents, ranging from $\leq 38 \%$ in the $\mathrm{HaCaT}^{\mathrm{pEF}}$ cell group to $\leq 54 \%$ in the $\mathrm{HaCaT}^{\mathrm{PSOkd}}$ group. A similar pattern to that of adhesion was observed in cell migration (Fig. 6B) and $\mathrm{HaCaT}^{\mathrm{EF}}$ cell migration was significantly increased by FAK inhibition $(\mathrm{P}<0.001)$.

\section{Discussion}

The expression of the S100 family calcium responsive signalling protein Psoriasin was studied in normal and chronic wound tissue. IHC staining for Psoriasin was visualized, and results were in accordance with the known expression patterns of Psoriasin in wound tissue (39). The present study

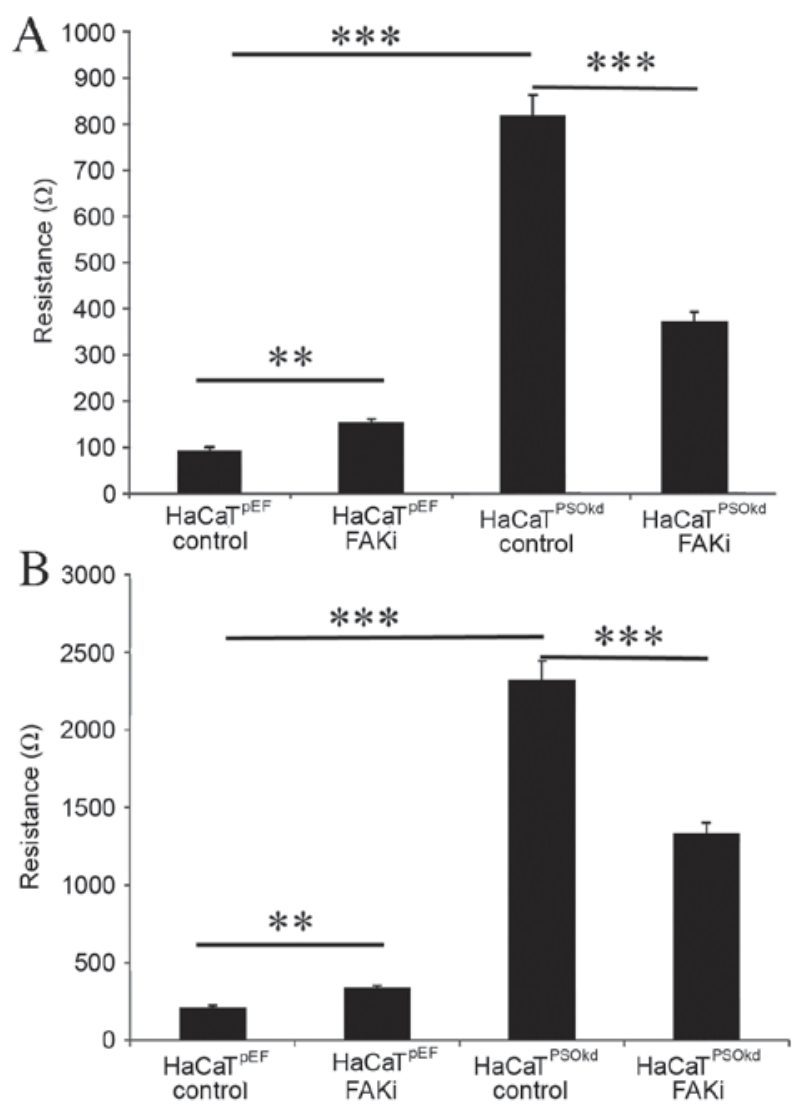

Figure 6. Association of FAK in the Psoriasin knockdown altered adhesion and migration of HaCaT cells. (A) FAK inhibitor significantly increase the rate of adhesion in $\mathrm{HaCaT}^{\mathrm{pF}}$ cells by $38 \%(\mathrm{P}<0.01)$. Within the HaCaT $\mathrm{CPSk}^{\mathrm{PSO}}$ cells there is a significant reduction of $54 \%$ in the adhesion rate with FAK inhibition. (B) FAK inhibition significantly increases the rate of cell migration in $\mathrm{HaCaT}^{\mathrm{pFF}}$ control cells by $57 \%(\mathrm{P}<0.01)$. FAK inhibition significantly reduces the rate of cell migration in $\mathrm{HaCaT}^{\text {PSOkd }}$ cells by a factor of $42 \%$. The absolute resistance is presented as the mean \pm the standard error of the mean. ${ }^{* * *} \mathrm{P}<0.001 ;{ }^{* *} \mathrm{P}<0.01$. FAK, focal adhesion kinase; i, inhibition; pEF, transfected with an empty vector; PSOkd, Psoriasin knockdown.

demonstrated a $19.8 \%$ increase in Psoriasin levels at the leading wound edge of the chronic wound compared with the distal end. This is consistent with previous reports of increased Psoriasin expression within wounds (39). However, within the chronic wound phenotype, Psoriasin mRNA levels are not significantly increased when compared with normal skin. This suggests that chronic wounds may be influenced by reduced Psoriasin expression; however, further study is required to clarify its value as a chronic wound biomarker. The findings of the present study correlate with the available data that Psoriasin expression is significantly increased in acute wounds (39). This suggests that Psoriasin has a notable influence at the leading wound edge in chronic wounds, and in acute wounds. Furthermore, Psoriasin may have an application as a biomarker for wound phenotyping and may also be used therapeutically to alter cell behaviour and increase wound healing rates. In conjunction with other cells types, the role of keratinocytes is critical in the healing of chronic cutaneous wounds. Their main function is to re-epithelialize the wound surface, thereby re-establishing epidermal cover, integrity and barrier function. This process encompasses a series of steps including proliferation, migration and differentiation $(46,47)$. 
To study some of these effects in vitro, the naturally immortalised $\mathrm{HaCaT}$ cell line was used.

In order to examine the effects of Psoriasin in keratinocytes, an in vitro model downregulating Psoriasin in $\mathrm{HaCaT}$ was used. Psoriasin knockdown was chosen as Psoriasinis already expressed in normal keratinocytes. The proliferation crystal violet assay identified a significant increase in the growth rate of $\mathrm{HaCaT}^{\mathrm{PSOkd}}$ cells compared with $\mathrm{HaCaT}^{\mathrm{pEF}}$ controls. Together with the expression pattern seen in the IHC of Psoriasin in wounds, this suggests that Psoriasin may serve differential roles in different locations within wound tissues, such as cells proximal and distal to wound edges. Upregulation of Psoriasin production and secretion was initially noted among psoriatic skin lesions (16) and was subsequently attributed to inflammation $(23,24)$. However, further evidence of elevated Psoriasin expression in bladder and breast cancer was observed $(17,29)$. Furthermore, an increase in Psoriasin expression levels was demonstrated among precancerous skin lesions and malignant epithelial tumours (squamous and basal cell carcinomas) (28), independent of differentiation and inflammation. It has therefore been suggested that this overexpression may be an important factor in tumour proliferation and progression.

Similarly, when compared with the corresponding $\mathrm{HaCaT}$ pEF6 control, in vitro ECIS migration assays show that downregulation of Psoriasin in $\mathrm{HaCaT}$ cells results in a significant increase in the rate of cell migration across a wounded area. At present, this increased migratory effect has only been noted in association with Psoriasin overexpression, similar to cell proliferation, which has also led to attributing Psoriasin to cancer progression. In addition, adhesion was found to be significantly increased, which is in accordance with previous findings where loss of adhesion, attributed to cancer cell invasiveness and progression, was associated with the upregulation of Psoriasin. The in vitro findings of the present study therefore suggest that increased cellular adhesion associated with downregulation of Psoriasin may explain the phenomenon of cancer progression from reduced adhesion, as has been noted with Psoriasin overexpression.

The results of the present study conflict somewhat, in that significantly lower levels of Psoriasin are present in chronic wound tissue compared with acute wound tissue and ribozyme suppression of Psoriasin expression in $\mathrm{HaCaT}$ cells enhanced cell migration and growth, which are traits typically found in healing tissues. The mechanisms underlying this are currently unknown, however it may be hypothesized that these findings will likely be due to the inherent differences between in vitro models and complex tissue, comprising multiple cell types, cytokine and growth factors. It is possible that Psoriasin may have a prominent role in $\mathrm{HaCaT}$ biology, although this may only be obvious or significant when various other complex factors and interactions are also considered.

The high expression of Psoriasin in abnormal and proliferative lesions of squamous epithelia $(18,26,48)$ suggest that it serves a role in the regulation of cell growth and survival. The contrasting evidence of increased migration and cell proliferation with Psoriasin knockdown may suggest that an alternative pathway, which is blocked by Psoriasin, stimulates cell growth and migration. However, the increased adhesion with knockdown suggests that Psoriasin downregulation is unlikely to be associated with cancer proliferation. Overall,
Psoriasin function appears to be important in maintaining cellular homeostasis, particularly with respect to cell proliferation, migration, adhesion and differentiation.

N-WASP is a member of the Wiskott-Aldrich syndrome family of proteins, which are widely involved in signal transduction from receptors on the cell surface to the actin cytoskeleton. The actin cytoskeleton is a dynamic filament network that is essential for cell movement, polarisation, morphogenesis and cell division, which was first described as a $65 \mathrm{kDa}$ protein from the brain that bound to $\mathrm{SH} 3$ domains of Ash/Grb2 (49). Having a sequence that was 50\% homologous with Wiskott- Aldrich syndrome protein (WASP), this novel protein was termed N-WASP $(50,51)$.

$\mathrm{N}$-WASP has been implicated in various actin-dependent processes, such as filopodium formation and the motility of Shigella (52). N-WASP and complexes with other proteins, such as Arp2/3, comprise a core mechanism for the stimulation of actin polymerisation and actin assembly $(53,54)$. A reduction of N-WASP has been shown to be associated with a greater malignant potential in breast cancer via its role in cell migration and invasion, and interaction with FAK $(55,56)$. In keratinocytes, knockout of N-WASP has previously been shown to reduce cellular proliferation (57). However, in-house studies (Jiang et al, unpublished data), have revealed increased keratinocyte migration in vitro with N-WASP inhibition by using the inhibitor wiskostatin. Similarly, inhibiting N-WASP by applying inhibitors topically and via the intraperitoneal route to mice enhanced wound closure rates (Jiang et al, unpublished data). As a result of these findings, a patent has been put in place to develop this product into a licensed treatment for hard-to-heal ulcers (Cardiff University patent, March 2009, ID 090 4886.9) (58).

ROCK1 and 2 occur in mammals (59) and are part of a group of kinases belonging to the AGC family of serine-threonine kinases. They are primarily involved in cell shape regulation, actin organisation on the cytoskeleton and hence cell migration. ROCK1 has a wide range of cellular functions including cellular contractility, migration, cytokinesis and cell-cell adhesion, via its downstream effector function of small GTPase Rho, which is a major cytoskeleton regulator $(60,61)$. ROCK 2 is primarily located in the brain and heart $(62,63)$. These kinasesalso serve an important role in smooth muscle contractility, neuronal development and nerve generation (64). Elevated ROCK protein levels in human breast, hepatocellular, bowel and bladder cancers have been demonstrated to correlate with increased tumour grade and poor overall survival rates $(64,65)$. In keratinocytes, differentiation is prevented and proliferation increased by ROCK inhibition, and a two-fold upregulation in Psoriasin following activation of ROCK2 has also been reported (66). ROCK-signalling pathways serve important roles in various human diseases and have been considered as potential targets for the treatment of these diseases, including cancer, leading to increased interest in the pharmacological potential of ROCK inhibitors (67). In terms of wound healing, ROCK inhibitors have previously been demonstrated to enhance corneal endothelial healing (68).

FAK, also known as protein tyrosine kinase 2 , is a focal adhesion-associated protein kinase encoded in humans by the PTK2 gene. This cytoplasmic protein tyrosine kinase is found concentrated in the focal adhesions that form among cells 
attaching to extracellular matrix (ECM) constituents (69). Most cells express FAK, and activation of the FAK tyrosine kinase promote cell contacts with ECM and promotes cell migration (69). The most well-characterised mechanism promoting FAK activation is integrin receptor clustering upon the binding of cells to ECM proteins, which leads to FAK dimerisation, autophosphorylation, SRC-family kinase binding and activated complex formation (69-71).

FAK is a multifunctional regulator of cell signalling within a tumour microenvironment, and is overexpressed and activated in several advanced stage-solid cancers (72). An increase in FAK mRNA levels has been demonstrated in serous ovarian tumours, invasive breast cancers, head and neck squamous cell carcinoma, colorectal malignancy and various other human malignancies (72). At the cellular level, FAK is thought to be associated with various signalling pathways that promote cancer growth and metastasis. It increases cell motility via ARP2/3, affects survival via p53 and MDM2 and induces cell cycle progression via cyclin D1 SRC-ERK or JUN (72). Small molecule FAK inhibitors have chemotherapeutic potential, as indicated in mouse models where FAK inhibition has been demonstrated to prevent tumour growth, metastasis, vascular permeability and angiogenesis (73-75). Among keratinocytes FAK has previously been revealed to be necessary for cell survival in vitro due to massive apoptosis, although this is not true in vivo. The same study group established FAK expression in mouse epidermis, thinner epidermis/hair cycle irregularities with no effect on wound healing rates in FAK knockdown mice (76). To our knowledge, no reports currently exist studying interactions between FAK and Psoriasin.

In conclusion, Psoriasin is expressed in keratinocytes and is a fundamental regulator of keratinocyte migration. Significant increases in the rate of keratinocyte adhesion, migration and growth have been observed in Psoriasin-deficient cells. N-WASP, FAK, and ROCK proteins serve certain roles in the Psoriasin-regulated cell adhesion and motility, implicating that Psoriasin may be associated with wound healing, thereby endorsing Psoriasin as a molecule of interest and a potential wound biomarkers.

\section{Acknowledgements}

The authors wish to thank Cancer Research Wales, Welsh Government A4B Scheme and Welsh Life Science Network-Ser Cymru for supporting the present study.

\section{References}

1. Gottrup F and Apelqvist J: The challenge of using randomized trials in wound healing. Br J Surg 97: 303-304, 2010.

2. Leaper DJ, Harding, KJ and Harding KG: The future of wound healing. In: Wounds: Biology and Management. Leaper DJ and Harding KJ (ed). Oxford University Press, Oxford, p191, 1998.

3. Posnett $\mathbf{J}$ and Franks PJ: The costs of skin breakdown and ulceration in the UK. In: Skin Breakdown: The Silent Epidemic. Pownall M (ed). Hull: Smith \& Nephew Foundation, pp6-12, 2007.

4. Abstract of Statistics-Quarter 3, 2011

5. Menke NB, Ward KR, Witten TM, Bonchev DG and Diegelmann RF: Impaired wound healing. Clin Dermatol 25: 19-25, 2007.

6. Bucalo B, Eaglstein WH and Falanga V: Inhibition of cell proliferation by chronic wound fluid. Wound Repair Regen 1: 181-186, 1993.
7. Harding KG, Morris HL and Patel GK: Science, medicine and the future: Healing chronic wounds. BMJ 324: 160-163, 2002.

8. Vaalamo M, Leivo T and Saarialho-Kere U: Differential expression of tissue inhibitors of metalloproteinases (TIMP-1, $-2,-3$ and -4) in normal and aberrant wound healing. Hum Pathol 30: 795-802, 1999.

9. Ravanti L and Kähäri VM: Matrix metalloproteinases in wound repair (review). Int J Mol Med 6: 391-407, 2000.

10. Brandner JM, Zacheja S, Houdek P, Moll I and Lobmann R: Expression of matrix metalloproteinases, cytokines, and connexins in diabetic and nondiabetic human keratinocytes before and after transplantation into an ex vivo wound-healing model. Diabetes Care 31: 114-120, 2008.

11. Telgenhoff D and Shroot B: Cellular senescence mechanisms in chronic wound healing. Cell Death Differ 12: 695-698, 2005.

12. Herrick SE, Sloan P, McGurk M, Freak L, McCollum CN and Ferguson MW: Sequential changes in histologic pattern and extracellular matrix deposition during the healing of chronic venous ulcers. Am J Pathol 141: 1085-1095, 1992.

13. Brem H, Stojadinovic O, Diegelmann RF, Entero H, Lee B, Pastar I, Golinko M, Rosenberg $\mathrm{H}$ and Tomic-Canic M: Molecular markers in patients with chronic wounds to guide surgical debridement. Mol Med 13: 30-39, 2007.

14. Tomic-Canic M, Ayello EA, Stojadinovic O, Golinko MS and Brem H: Using gene transcription patterns (bar coding scans) to guide wound debridement and healing. Adv Skin Wound Care 21: 487-494, 2008.

15. Charles CA, Tomic-Canic M, Vincek V, Nassiri M, Stojadinovic O, Eaglstein WH and Kirsner RS: A gene signature of nonhealing venous ulcers: Potential diagnostic markers. J Am Acad Dermatol 59: 758-771, 2008.

16. Madsen P, Rasmussen HH, Leffers H, Honoré B, Dejgaard K, Olsen E, Kiil J, Walbum E, Andersen AH, Basse B, et al: Molecular cloning, occurrence, and expression of a novel partially secreted protein 'psoriasin' that is highly up-regulated in psoriatic skin. J Invest Dermatol 97: 701-712, 1991.

17. Celis JE, Cruger D, Kiil J, Lauridsen JB, Ratz G, Basse B and Celis A: Identification of a group of proteins that are strongly up-regulated in total epidermal keratinocytes from psoriatic skin. FEBS Lett 262: 159-164, 1990.

18. Watson PH, Leygue ER and Murphy LC: Psoriasin (S100A7). Int J Biochem Cell Biol 30: 567-571, 1998.

19. Schäfer BW and Heizmann CW: The S100 family of EF-hand calcium-binding proteins: Functions and pathology. Trends Biochem Sci 21: 134-140, 1996.

20. Wicki R,Schafer BW,Erne P and Heizmann CW: Characterization of the human and mouse cDNAs coding for S100A13, a new member of the S100 protein family. Biochem Biophys Res Commun 227: 594-599, 1996.

21. Børglum AD, Flint T, Madsen P, Celis JE and Kruse TA: Refined mapping of the psoriasin gene S100A7 to chromosome 1cen-q21. Hum Genet 96: 592-596, 1995.

22. Heizmann CW and Hunziker W: Intracellular calcium-binding proteins: More sites than insights. Trends Biochem Sci 16: 98-103, 1991.

23. Algermissen B, Sitzmann J,LeMotte P and Czarnetzki B: Differential expression of CRABP II, psoriasin and cytokeratin 1 mRNA in human skin diseases. Arch Dermatol Res 288: 426-430, 1996.

24. Jinquan T, Vorum H, Larsen CG, Madsen P, Rasmussen HH, Gesser B, Etzerodt M, Honoré B, Celis JE and Thestrup-Pedersen K: Psoriasin: A novel chemotactic protein. J Invest Dermatol 107: 5-10, 1996.

25. Alowami S, Qing G, Emberley E, Snell L and Watson PH: Psoriasin (S100A7) expression is altered during skin tumorigenesis. BMC Dermatol 3: 1, 2003.

26. Enerback C, Porter DA, Seth P, Sgroi D, Gaudet J, Weremowicz S, Morton CC, Schnitt S, Pitts RL, Stampl J, et al: Psoriasin expression in mammary epithelial cells in vitro and in vivo. Cancer Res 62: 43-47, 2002.

27. Leygue E, Snell L, Hiller T, Dotzlaw H, Hole K, Murphy LC and Watson PH: Differential expression of psoriasin messenger RNA between in situ and invasive human breast carcinoma. Cancer Res 56: 4606-4609, 1996.

28. Moubayed N, Weichenthal M, Harder J, Wandel E, Sticherling M and Gläser R: Psoriasin (S100A7) is significantly up-regulated in human epithelial skin tumours. J Cancer Res Clin Oncol 133: 253-261, 2007.

29. Al-Haddad S, Zhang Z, Leygue E, Snell L, Huang A, Niu Y, Hiller-Hitchcock T, Hole K, Murphy LC and Watson PH: Psoriasin (S100A7) expression and invasive breast cancer. Am J Pathol 155: 2057-2066, 1999. 
30. Carlsson H, Yhr M, Petersson S, Collins N, Polyak K and Enerbäck C: Psoriasin (S100A7) and calgranulin-B (S100A9) induction is dependent on reactive oxygen species and is downregulated by Bcl-2 and antioxidants. Cancer Biol Ther 4 998-1005, 2005.

31. Emberley ED, Alowami S, Snell L, Murphy LC and Watson PH: S100A7 (psoriasin) expression is associated with aggressive features and alteration of Jab1 in ductal carcinoma in situ of the breast. Breast Cancer Res 6: R308-R315, 2004

32. Emberley ED, Niu Y, Leygue E, Tomes L, Gietz RD, Murphy LC and Watson PH: Psoriasin interacts with Jabl and influences breast cancer progression. Cancer Res 63: 1954-1961, 2003.

33. Jiang WG, Watkins G, Douglas-Jones A and Mansel RE: Psoriasin is aberrantly expressed in human breast cancer and is related to clinical outcomes. Int J Oncol 25: 81-85, 2004.

34. Hoffmann HJ, Olsen E, Etzerodt M, Madsen P, Thøgersen HC Kruse T and Celis JE: Psoriasin binds calcium and is upregulated by calcium to levels that resemble those observed in normal skin. J Invest Dermatol 103: 370-375, 1994.

35. Rasmussen HH, Orntoft TF, Wolf $\mathrm{H}$ and Celis JE: Towards a comprehensive database of proteins from the urine of patients with bladder cancer. J Urol 155: 2113-2119, 1996.

36. Eckert RL, Broome AM, Ruse M, Robinson N, Ryan D and Lee K: S100 proteins in the epidermis. J Invest Dermatol 123: 23-33, 2004.

37. Mansbridge JN and Knapp AM: Changes in keratinocyte maturation during wound healing. J Invest Dermatol 89: 253-263, 1987.

38. McKay IA and Leigh IM: Altered keratinocyte growth and differentiation in psoriasis. Clin Dermatol 13: 105-114, 1995.

39. Dressel S, Harder J, Cordes J, Wittersheim M, Meyer-Hoffert U, Sunderkötter C and Gläser R: Differential expression of antimicrobial peptides in margins of chronic wounds. Exp Dermatol 19: 628-632, 2010

40. Conway K, Ruge F, Price P, Harding KG and Jiang WG: Hepatocyte growth factor regulation: An integral part of why wounds become chronic. Wound Repair Regen 15: 683-692, 2007.

41. Conway KP, Price P, Harding KG and Jiang WG: The role of vascular endothelial growth inhibitor in wound healing. Int Wound J 4: 55-64, 2007.

42. Ye L, Sun PH, Martin TA, Sanders AJ, Mason MD and Jiang WG: Psoriasin (S100A7) is a positive regulator of survival and invasion of prostate cancer cells. Urol Oncol 31: 1576-1583, 2013.

43. Jiang WG, Douglas-Jones A and Mansel RE: Expression of peroxisome-proliferator activated receptor-gamma (PPAR $\gamma)$ and the PPARgamma co-activator, PGC-1, in human breast cancer correlates with clinical outcomes. Int J Cancer 106: 752-757, 2003

44. Jiang WG, Martin TA, Lewis-Russell JM, Douglas-Jones A Ye L and Mansel RE: Eplin-alpha expression in human breast cancer, the impact on cellular migration and clinical outcome. Mol Cancer 7: 71, 2008.

45. Keese CR, Wegener J, Walker SR and Giaever I: Electrical wound-healing assay for cells in vitro. Proc Natl Acad Sci USA 101: 1554-1559, 2004

46. Bereiter-Hahn J, MatolsyA G and Sylvia Richards K (eds): Epidermal cell migration and wound repair. In: Biology of the Integument 2 Vertebrates. Berlin: Springer-Verlag 444-447, 1986.

47. Patel GK, Wilson $\mathrm{CH}$, Harding KG, Finlay AY and Bowden PE: Numerous keratinocyte subtypes involved in wound re-epithelialization. J Invest Dermatol 126: 497-502, 2006.

48. Ostergaard M, Wolf H, Orntoft TF and Celis JE: Psoriasin (S100A7): A putative urinary marker for the follow-up of patients with bladder squamous cell carcinomas. Electrophoresis 20: 349-354, 1999.

49. Miki H, Miura K and Takenawa T: N-WASP, a novel actin-depolymerizing protein, regulates the cortical cytoskeletal rearrangement in a PIP2-dependent manner downstream of tyrosine kinases. EMBO J 15: 5326-5335, 1996.

50. Fukuoka M, Miki H and Takenawa T: Identification of N-WASP homologs in human and rat brain. Gene 196: 43-48, 1997.

51. Fukuoka M, Suetsugu S, Miki H, Fukami K, Endo T and Takenawa T: A novel neural Wiskott-Aldrich syndrome protein (N-WASP) binding protein, WISH, induces Arp $2 / 3$ complex activation independent of Cdc42. J Cell Biol 152: 471-482, 2001.

52. Uruno T, Liu J,Li Y, Smith N and Zhan X: Sequential interaction of actin-related proteins 2 and 3 (Arp2/3) complex with neura Wiscott-Aldrich syndrome protein (N-WASP) and cortactin during branched actin filament network formation. J Biol Chem 278: 26086-26093, 2003.
53. Weaver AM, Heuser JE, Karginov AV, Lee WL, Parsons JT and Cooper JA: Interaction of cortactin and N-WASp with Arp2/3 complex. Current Biol 12: 1270-1278, 2002.

54. Rohatgi R, Ma L, Miki H, Lopez M, Kirchhausen T, Takenawa T and Kirschner MW: The interaction between N-WASP and the Arp2/3 complex links Cdc42-dependent signals to actin assembly. Cell 97: 221-231, 1999.

55. Martin TA, Pereira G, Watkins G, Mansel RE and Jiang WG: N-WASP is a putative tumour suppressor in breast cancer cells, in vitro and in vivo and is associated with clinical outcome in patients with breast cancer. Clin Exp Metastasis 25: 97-108, 2008.

56. Sanchez AM, Flamini MI, Baldacci C, Goglia L, Genazzani AR and Simoncini T: Estrogen receptor-alpha promotes breast cancer cell motility and invasion via focal adhesion kinase and N-WASP. Mol Endocrinol 24: 2114-2125, 2010.

57. Lefever T,Pedersen E, Basse A, Paus R, Quondamatteo F, Stanley AC, Langbein L, Wu X, Wehland J, Lommel S and Brakebusch C: $\mathrm{N}-$ WASP is a novel regulator of hair-follicle cycling that controls antiproliferative TGF\{beta\} pathways. J Cell Sci 123: 128-140, 2010.

58. Jiang $W$ and Harding $K$ : Method and kit for the classification and prognosis of wounds. Journal, 2010.

59. Reese KA, Reddy S and Rock JA: Endometriosis in an adolescent population: The Emory experience. J Pediatr Adolesc Gynecol 9: $125-128,1996$

60. Riento K and Ridley AJ: Rocks: Multifunctional kinases in cell behaviour. Nat Rev Mol Cell Biol 4: 446-456, 2003.

61. Yasui Y, Amano M, Nagata K, Inagaki N, Nakamura H, Saya H, Kaibuchi $\mathrm{K}$ and Inagaki M: Roles of Rho-associated kinase in cytokinesis; mutations in Rho-associated kinase phosphorylation sites impair cytokinetic segregation of glial filaments. J Cell Biol 143: 1249-1258, 1998.

62. Zhou Z, Meng Y, Asrar S, Todorovski Z and Jia Z: A critical role of Rho-kinase ROCK2 in the regulation of spine and synaptic function. Neuropharmacology 56: 81-89, 2009.

63. Zhao Z and Rivkees SA: Rho-associated kinases play a role in endocardial cell differentiation and migration. Dev Biol 275: 183-191, 2004.

64. Morgan-Fisher M, Wewer UM and Yoneda A: Regulation of ROCK activity in cancer. J Histochem Cytochem 61: 185-198, 2013.

65. Lane J, Martin TA, Watkins G, Mansel RE and Jiang WG: The expression and prognostic value of ROCK I and ROCK II and their role in human breast cancer. Int J Oncol 33: 585-593, 2008.

66. McMullan R, Lax S, Robertson VH, Radford DJ, Broad S, Watt FM, Rowles A, Croft DR, Olson MF and Hotchin NA: Keratinocyte differentiation is regulated by the Rho and ROCK signaling pathway. Curr Biol 13: 2185-2189, 2003.

67. Hahmann $\mathrm{C}$ and Schroeter T: Rho-kinase inhibitors as therapeutics: From pan inhibition to isoform selectivity. Cell Mol Life Sci 67: 171-177, 2010.

68. Okumura N, Koizumi N, Ueno M, Sakamoto Y, Takahashi H, Hirata K, Torii R, Hamuro J and Kinoshita S: Enhancement of corneal endothelium wound healing by Rho-associated kinase (ROCK) inhibitor eye drops. Br J Ophthalmol 95: 1006-1009, 2011.

69. Brami-Cherrier K, Gervasi N, Arsenieva D, Walkiewicz K, Boutterin MC, Ortega A, Leonard PG, Seantier B, Gasmi L, Bouceba T, et al: FAK dimerization controls its kinase-dependent functions at focal adhesions. EMBO J 33: 356-370, 2014.

70. Parsons JT: Focal adhesion kinase: The first ten years. J Cell Sci 116: 1409-1416, 2003.

71. Schaller MD: Cellular functions of FAK kinases: Insight into molecular mechanisms and novel functions. J Cell Sci 123: 1007-1013, 2010

72. Sulzmaier FJ, Jean C and Schlaepfer DD: FAK in cancer: Mechanistic findings and clinical applications. Nat Rev Cancer 14: 598-610, 2014.

73. Parsons JT, Slack-Davis J, Tilghman R and Roberts WG: Focal adhesion kinase: Targeting adhesion signaling pathways for therapeutic intervention. Clin Cancer Res 14: 627-632, 2008.

74. Shi Q, Hjelmeland AB, Keir ST, Song L, Wickman S, Jackson D, Ohmori O, Bigner DD, Friedman HS and Rich JN: A novel low-molecular weight inhibitor of focal adhesion kinase, TAE226, inhibits glioma growth. Mol Carcinog 46: 488-496, 2007.

75. Roberts WG, Ung E, Whalen P, Cooper B, Hulford C, Autry C, Richter D, Emerson E, Lin J, Kath J, et al: Antitumor activity and pharmacology of a selective focal adhesion kinase inhibitor, PF-562,271. Cancer Res 68: 1935-1944, 2008

76. Essayem S, Kovacic-Milivojevic B, Baumbusch C, McDonagh S, Dolganov G, Howerton K, Larocque N, Mauro T, Ramirez A, Ramos DM, et al: Hair cycle and wound healing in mice with a keratinocyte-restricted deletion of FAK. Oncogene 25: 1081-1089, 2006 